\title{
The Dialectic Dimensions of Architectural Identity in Heritage Conservation, The Case of Amman city
}

\author{
Dr. Jawdat Goussous ${ }^{1}$, Dareen Qashmar ${ }^{2}$ \\ The University of Jordan, School of Engineering, Department of Architecture Engineering 1,2
}

\begin{abstract}
In conventional areas of architectural design, heritage conservation, history and literature, architectural identity is often conceived and represented as a timeless and historically stable entity. This is reflected in particular practices of building design and heritage conservation that view and portray architectural identity in terms of aesthetics or built form, these representations and ideas of architecture portray identity as an immutable and historically continuous subject of knowledge.

This paper first offers theoretical framework to maintain the identification of identity, architectural identity, and national identity. It also raises the issue of identity in general and in architecture as a multi- disciplinary concept. This paper deals with the impact of local culture on shaping the architectural identity. Furthermore, investigate the transformative nature of architecture and the identity, drawing on cultural, historical concepts of meaning as a theoretical framework which discussed by theorists such as Bourdieu, Foucault and Barthesto. And also shed light on the architectural identity in the city of Amman reading and analyzing previous studies about Amman's identity to deduct the main features of architectural styles in Amman and the reason of difficult finding a unified architectural identity.
\end{abstract}

Key words: Identity, Architectural Identity, Heritage Conservation, Culture.

\section{Introduction}

Identity conservation (moral, physical, cultural) one of the most prominent Arab issues raised for research and study, and that its importance and seriousness of the Arab nation, especially because we live in the era of "globalization" new world order characterized by the information revolution in the various means of communication (Internet, techniques, Electronic.... and others), which targets different dimensions of our life (political, economic, social and especially cultural).

This threatens our Arab nation, which has long characterized by its cultural and religious personality and distinctive intellectual wealth, manifested itself throughout the ages, and met with respect and appreciation of different cultures for their world. And the imposition of American cultural (as a source of globalization) with its global, economic, military and technical influence, at the same time the promotion of the best cultures and the extension of cultural hegemony able substitute for our Arab culture.

The framework of the Arab identity depends on the following: 


\section{International Conference on Advanced Research in SOCIAL SCIENCES}

March 7-9,2019, London - United Kingdom

- Religion: It is well known that the idea of debt associated with human beings since its existence is also an integral component of the mouthpiece of the community identity.

- Custom: The custom frame the reference for any society, because it determines the privacy and identity and sets it apart from other communities, also varies from one community to the other by its nature and its values.

- Language: is the title for any nation to determine her personality and identity, it is a tool for expression, to translate thoughts, ideas and feelings, it is a way of understanding, learning, development ,transfer of experiences, cultures and civilizations.

- Geographic: determine the natural territorial border of any nation, including the Provisions of ethnicities, nationalities and peoples, so that brought together by circumstances, fate and single goals.

Every city holds its story within informal features that can be read on its walls. It can reveal its countenance from the patterns on its facades, its graffiti, its furniture, and misty neighborhoods. Thus the process of cultural expression throughout architecture reflecting on urbanized form requires the condensation of an array of its historic/human/ecological/climatic ethos into signified phenomena without any reduction or subjugation of narrative.

\section{Literature Review:}

Through this part some previous studies that addressed this subject was reviewed in order to be a reference utilized during this research and built upon it new knowledge and information, to integrated a holistic view of the topic .

1. Jennifer Tran, 2009. Static Illusions: Architectural Identity, Meaning and History. Curtin University.

2. James D. Fearon. November 3, 1999. What is identity ( as we now use the word?).

3. Department of Political Science. Stanford University.

4. Huzam Kaddoura. Siham Malkawi.Ontology of Amman: Soul and Body: study of the development of the Arab modern city.

5. Dr.Mamdouh Al-Abadi.1996. Amman :Realities and expectations.issue on cultural, environment and construction.conference held at the royal Cultural Center, Amman,27-29 June 1995.

\section{Research objectives}

- Find the reasons that led the absence of a unified architectural identity in Amman city. 


\section{International Conference on Advanced Research in SOCIAL SCIENCES}

March 7-9, 2019, London - United Kingdom

- Attempt to extrapolate the main features of the architecture in the city of Amman.

- Find the suitable definition of Identity in a multidisciplinary approach.

- Identify the meaning of the architectural identity and the controversy over this concept.

\section{Research Methodology}

The research philosophy that guided this study employed descriptive and deductive approach to cover the study aspects and to implement the objectives of this study by reviewing the theoretical background of term identity within multidisciplinary approaches.

Within this approach this research focuses on how the way that conservation and promotion of particular local histories and cultures defines the contemporary character of the town identity by discussed the relationship between heritage, conservation and architectural identity. Then the main features of architectural styles in Amman was introduced. Reading and analyzing previous studies about Amman's identity to deduct the reason of difficult finding a unified architectural identity, in addition to photographic documentation. As a result of this study conclusion are presented suggested that further studies on the cultural, contextual and historically transformative aspects of architectural identity are necessary in order to obtain a more critical understanding of the built environment.

\section{Amman city}

\section{Historical background}

Amman is a modern city, although its history dates back 9000 years. At the beginning of the 20th century, in 1922 Amman became the capital of Jordan. Development of the city of Amman, over time, influenced by several external factors including: migration of Palestinian refugees who have settled in on 1948, and 1967.1991 after the Gulf War many of Jordanian workers returning from Kuwait and Iraq. All these factors led to the sudden and rapid increase in population so that resulting in Amman Municipality to develop a comprehensive plan for the city of Amman.1956 the first comprehensive plan was introduced, 1978 another comprehensive plan introduced and $\mathrm{Al}$ Abdali district started to appear at that time. 1988 the metropolitan comprehensive plan for greater Amman was developed, this phase was marked by the advent of erecting high rise building in excess of 100 meters in the Amman area.

All of these factors increasing diversity of the Amman's citizens and found different social/ geographic/economic/ethnic/historic layers, which have important implications for how they, both immigrants and non-immigrants alike, define themselves culturally and also differentiate the whole city identity. A number of constructs have been referred to as aspects of identity formation including acculturation strategies, ethnic identity, individualist and collectivist cultural orientations, and independent and interdependent self- construe. Individual differences may exist between people residing in a primarily individualist (e.g. their homes), or primarily collectivist context, these differences reflect variations in identity. 


\section{International Conference on Advanced Research in SOCIAL SCIENCES}

The political ideology of the city plays an important role in the globalization process as described by Newman and Thornely, which is currently taking place in Amman. Amman's situation is a mixture between state control and economic liberalism in which urban development is determined by the planning vision of attracting foreign investment and reduced restrictions to free enterprise.

The site in Amman is presented in its mountain environment that is described with its height variances of sea level and enjoys a moderate breeze most of the year. Amman abides by the rule that states that cities are constructed on the edges of rivers and lakes, since it is the city of streams in reference to the novelist Abed Rahman Muneef. The water used to flow from various places and meet in the river, the first stream evolved from Ras Al-Eeen in the west of the old city. The river initiates its first step breaching the city from west to east, and after a long pace meets with the River of Zarqaa as both pour in the River of Jordan. Between the high mountains Amman was a giving farm and basket of wheat for Roma then for Ottomans. Height means supervision, from this point the castle was founded, since the old ages when the beautiful Tyche the daughter of Zeus who brought luck and protected Amman.

It has a unique essence, derived from each civilization, its castle is a symbol for loftiness, pride and solidity; its theater with the massive stadium is a symbol for civilization, sophistication and literature; whereas The Mermaid Spa' stores several religious and cultural symbols. It is the beautiful corona and the queen of secrets, the Romans were right when symbolized its essence by addressing the place with the names of love and beauty (Philadelphia).

Between the old and new, the soul of Amman has a certain theme. It is the rooted mountain along with its unlimited heights that breaches the space in each direction. It is the narrow valley that reminds all mountains that it has sprouted from the same origin that is capable of embracing and uniting residents.

Every city holds its story within informal features that can be read on its walls. It can reveal its countenance from the patterns on its facades, its graffiti, its furniture, and misty neighborhoods. Thus the process of cultural expression throughout architecture reflecting on urbanized form requires the condensation of an array of its historic/human/ecological/climatic ethos into signified phenomena without any reduction or subjugation of narrative.

What is astonishing about our city is that it has been able to digest all divergent layers and structures of ethnic/religious/national/ economic/ architectural ethos. The intertwined social structure of our city has brought its simmering homogeneity. It is through the multiplicity of individual life projects and collective life forms that this community could ascend its evolving form of culture.

The attributes of a community structure lie beyond space and time, yet the processes of our daily lives lay foundation for a definite enclosure to our individual existance. Architecture acts as the keyplayer in translating our local needs into spaces, forms and typologies. Architecture acts as a form of expression. Architecture resolves the formula between cultural science and human needs and the inherent intuition of the artistic and aesthetic sense. 


\section{International Conference on Advanced Research in SOCIAL SCIENCES}

March 7-9,2019, London - United Kingdom

The genesis of modern Amman was outlined by the strategic connection of the Hejaz railroad linking together major cities of the Fertile Crescent with the Arabian Peninsula. But the British mandate laid grounds for the newborn city, their kinship crystallized in a grand residence for the Ambassador, a palace for the Prince overlooking the valley, a military base, a mosque and a church, and ceremonial street to celebrate national days. Dispersed around a strong Archeological historical background of the Roman Amphitheatre. The prime visual exemplar to the urbanizing growth of Amman was the Roman Amphitheatre. Then people settling on a mountain, building houses on the slope, what called for the articulation of stairways and the sloping neighborhoods growing around these vertical streams of flow. This buildup provided the vitality of the movement from the houses residing on the slope to the flat lands of the commercial areas and institutional centers like the court of justice.

Architecture began in the city of Amman with the immigration of Circassians, they established buildings and then established the emirate of Amman to be its capital, which has seen its impact migrations of technical manpower ,skilled builders and industrialists (from Palestine Lebanon and Syria), the architecture was simple formed the layering of gradual social, natural, urban, interplay which resolved into a simple juxtaposition of a single life form and the slogan of( A HOUSE: simple façade (confirm the principles of aesthetic interact with the natural environment and meet their needs), courtyard mediates rooms and links them ), building materials were taken from those found on the outskirts of the torrent of stones and trees . Even though the use of local stone and the art of masonry have managed to hold together a somewhat coherent image.

With the independence of Jordan and the emergence of Amman as the capital city, well established citizens had directed their efforts towards naissance of the city consensus through providing loans, real estate, and capital. These efforts were adjoined by migrating families from across the country expanding the city's infrastructure, building the University and an airport. Further planning of the city improved land use raising the value of real estate and incorporating existing structures to adapt government and public institutions.

The surrounding political situation of the region had been in a state of flux. Its sporadic pattern of change was evidently traced on the urban development of the city, until it reached a seasonal tide of growth and decline.

The lack of coherence revealed itself in a contamination of the city with competing typologies imported from western societies devoid of cultural reference. The appropriated models of postmodern architecture were not established on a theoretical base of departure, which creating a disparity between the true meaning of Semiotics and a dysfunctional articulation of facades and so on the identity had been lacking even in the postmodern approach towards our local architecture.

During the eighties alien architectural phenotypes threatening the morphology of Amman and its urban tissue, determining Capitalism through the monumental facades and applying steel and glass deformations to our buildings. The repulsive battle of styles became hardly unnoticeable in Amman, harassing the civic environment in an audacious use of western styles.

Even more globalized and cosmopolitan institutions such as banks, Hotels, and Cafe are dictating invalid behavior through franchised Protocols. Such institutions are not only imposing their spatial conditions, they are also inviting patterns of social interaction and behavior adequate 


\section{International Conference on Advanced Research in SOCIAL SCIENCES}

March 7-9,2019, London - United Kingdom

to these conditions. Even hospitals have transformed into health to commercial centre, reinforced by their capitalistic image. Coffee shops carry foreign names; follow appropriate etiquette to their foreign lifestyle conduit. Even food chains have rendered our streets, penetrating local schemata becoming famous landmarks of our city.

The latest invasion of Iraq, knocking down the last attempts to preserve the Ammani identity, by placing the modern pillars of capitalism and globalization. Such projects are financed by the same countries that are now faced with the social and climatic drawbacks of high rise buildings.

It is worth mentioning that the concept of "contemporary" does not mean subordination and commitment the other, it means to contribute the contemporary thought submit creations authentic not replicated. Remains intent, increase inventory creativity world and not repeat it. The Heritage is stock philanthropy, which is not determined in time that has passed, but in time continuous, from one to the other.

\section{Main features of architectural styles in Amman:}

- Use of white limestone for the construction of dwellings, ((most probably in the east of Amman). The built form seems to be a cluster type arrangement of several dwellings into one giving an impression of a much larger Scale to each building. The characteristic of the architecture has an almost organic sense to it, as if it has grown from the stony earth inadvertently forming dwellings for people to inhabit.

- The large masonry arches used in the construction of contemporary buildings forms another strong characteristic of the city. at first it is accepted that the formation of the arch is a logical method for creating large opening using the local limestone but modern construction uses the column and beam to transfer structural loads through the building therefore in modern buildings the arch loses its structural importance but continues to carry its characteristic quality.

- The house design: the home also reflects the individual's identity, tastes and values and maximises his or her freedom of choice to be unique and distinct, independent and free of the influences of others. It also discuss how the personalization of dwelling units varies with respect to economic, social, cultural and political factors that impinge upon the lifestyle of residents. Homes reflect the dialectic interplay of individuality and society--meaning.

The home depicts the uniqueness and individuality of its occupants, i.e. their personal identity as individuals and as a family, along with their ties, their own lifestyles, bonds and affiliations with the community and larger culture of which they are a part. while features of homes vary, they fall within the appropriate limits defined by the culture. The identity theme is clearly illustrated by considering recently-built neighborhoods, where homes are often initially quite similar in design.

- $\quad$ Skyscrapers buildings which constructed in spontaneous manner at any location or zone. Amman has three major dominate skyscrapers which will effect and influence on the skyline of the city: 


\section{International Conference on Advanced Research in SOCIAL SCIENCES}

March 7-9, 2019, London - United Kingdom

- Jordan Gate twin towers, under construction, it will become the highest building in Amman, 150 meters' height after its completion. Situated in the western section of the city of Amman near the main road connecting Amman to its airport.

- Al Abdali site, under construction, which will become the home for the seven skyscrapers in Amman vary in height from 100 meters, reaching to 220 meters, located in the western section of the city center.

\section{Difficulty of finding a unified architectural identity due to the following reasons:}

- The spread of the idea of progress in modern lifestyles which do not fit with its past, cultural and environmental realities, but tracking material gain financial and so lost the significance of architectural and cultural heritage.

- Technological advances in the different fields of science and civilization, especially in the field of architecture and advanced uses of modern building materials, or a valuable application of sophisticated construction systems set up depending on the economic data, income, administrative organization and planning theory.

- Raise the level of business investment to provide income.

- Contributed laws and legislation that Conversion the annex land adjacent to the archeological sites into areas for housing and giving licenses to set up housing to solve the problems of housing at the expense of development and the preservation of heritage buildings and archaeological historical, which led to the infringement of those buildings and a change in the features and landmarks, as occurred in the cities of Amman and Jerash.

- Multiplicity of architectural styles in design (loss the unified soul or style according to different schools and approaches, which often western style) because each architect seeking to put his own imprint (personal identity), which distinguish it from others and ignore the relationship between Amman's nature and the surrounding environment.

- The modern trend towards tourist Architecture, where the individuality formula is the prevailing patterns, overlapped construction and commercial offices, restaurants and cafes be within residential buildings, according to a purely Western trend.

- Visual pollution on the rooftops and in particular in the downtown, which attack the buildings facades which turned into billboards in random situations of disturbing and offensive.

- Tendency to show and highlight the self, bragging and showing off the use of architectural elements or ornamental materials lend inconsistent character with the local urban environment, by spending money in luxury building, luxury homes and the establishment of sophisticated construction. In while other areas showed a large variation in social and cultural organization, and in architectural style which characterized by indiscriminate and organic design, for example:

- High-tech and sophisticated buildings emerged (mostly imported from abroad).

- Buildings of a local style. 


\section{International Conference on Advanced Research in SOCIAL SCIENCES}

March 7-9,2019, London - United Kingdom

- Imitation in design style (cut and paste), which led to weakness in appearance and the low level of architectural and artistic taste.

Even so the collective social memory which connected with city of Amman, within its streets, inputs and the inclusion of small backyard is the living heritage which is difficult to break him, including emotions and it represents the belonging feelings to whom living in. Given this city its legality and form its identity.

As architect, planners and conservators we should create identity plan for our city to preserve and promote the uniqueness character of each zone, this plan including areas of conservation and redevelopment of the node points of mnemonic value particular to our community by identifying the social, commercial and recreational activity patterns. To build regional identity, we should incorporate an identity map for several zones, in this map shows icons ,activity node, focal points, essential routes and gathering places, which are landmarks in our social landscape by these procedures we can reinforce the distinctive identity to our city.

\section{Conclusion}

This research insight into the term of identity which becomes a remarkable phenomenon in the recent years, which become a modern formulation of dignity, pride, or honor that implicitly links these to social categories. it is taken an intense interest in many field which questions concerning identity, we can summarize its definition in ordinary speech and most academic writing; it means either (a) a social category, defined by membership rules and allegedly characteristic attributes or expected behaviors, or (b) a socially distinguishing feature that a person takes a special pride in or views as unchangeable but socially consequential (or, of course, both (a) and (b) at once. Identity is narrative constructed in an ongoing dialogue with culture, heritage and history. They are related to each other. Many buildings, landscapes and pieces of art are seen as heritage because they refer to certain historic periods, persons or events, and at the same time these constructs as aspects of identity formation, Heritage can act as a symbol and refer to stories of history. A number of objects that are preserved as heritage, date from specific epochs are also defines the contemporary character of the town identity. This term is used in a wider sense to refer not just to 'traditional' material objects but also to 'traditional' ways of life (often such overt, sensory and 'aesthetic' cultural forms as dance, drama, music, and the visual and plastic arts), which are usually brought into association with the material evidence of the past. Heritage is a stock that inspired generations and also proposes ideas for future solutions. So heritage is eventually about representation and constructing identities.

This research focuses on how the way that conservation and promotion of particular local histories and cultures defines the contemporary character of the town identity, even so architectural identity discussed to be understood as an unstable construct that forms and alters according to historically specific socio-cultural, perceptual and contextual conditions across time. familiarized by individuals and their particular encounters of the built environment. Additionally, the role of people's past experiences, memories and ideas in shaping architectural meaning (how people's 


\section{International Conference on Advanced Research in SOCIAL SCIENCES}

March 7-9,2019, London - United Kingdom

memories, past experiences or ideas, and their socio-cultural association with the built environment, play a pivotal role in the construction and transformation of architectural identity. In short, architecture should not be studied for its meaning, but for its meanings. As historians we are always translating architecture: not reading its message, but exploring its multiple transpositions.

City of Amman has different social/ geographic/economic/ethnic/historic layers which added something different to its identity. So we should -people as individuals and places as communitiesseek to preserve a sense of place, history and belonging in the context of intensive use of land. Identity is no longer confined to the built environment and physical characteristics alone, but also historical significance, community life, distinctive lifestyle and cultural traits, and even the soft aspect as social activities. Identity is more than just conservation we should identify the charm of our various places, the things which make them appealing to us and give us a sense of belonging rootedness and identity.

There seems to be a strong gap between the theoretical realm of education and the harsh world of practitioners that hinders a uniform scientific inquiry about the future of our city identity. We have been swayed against the real purpose of architecture on both the individual and urban level. It is truly a brilliant architect that can provide a comfortable living. If the purpose of education were to broaden our architectural perception and to emit an authentic cultural view, then we have as architects failed. We have only succeeded in extending our egocentric madness to the whole city. As architects and planners we need to transmit an honest narrative of our culture and digest the multicultural implications without causing a distortion of identity. As architects we should able for once to cleanse our eyes from western aesthetics and to hush our blinding ambition, and faced the scattered ideologies that they need to derive a stable identity from it. Let it be wise enough to build upon with science and technology that serves humanity and not destroys it at the same time preserve our cultural.. This suggests that further studies on the cultural, contextual and historically transformative aspects of architectural identity are necessary in order to obtain a more critical understanding of the built environment.

References:

Dr. Ahmad Shukri Yusof .Cultural Continuum and Architectural Identity: Learning organizations in Conservation.http://m08.cgpublisher.com/proposals/486/index_html

Appiah, Kwame Anthony and Henry Louis Gates Jr., eds. 1995. Identities. Chicago, IL: University of Chicago Press.

Barthes, Roland. 1977. "The death of the author." In Image-Music-Text, translated by Stephen heath, 142-148. Glasgow: Fontana.

Blaser, Werner. 1999. Mies van der Rohe: Farnsworth House. Basel: Birkhauser.

Bouke Van Gorp \& Hans Renes ,February 2006.AEuropean cultural identity? Heritage and shared histories in the European union.Faculty of Geosciences, Utrecht University, Heidelberglaan 2, 3508 TC Utrecht, the Netherlands.E-mails: b.vangorp@geo.uu.nl; j.renes@geo.uu.nl.

Bourdieu, Pierre. 1993. The Field of Cultural Production. Cambridge: Polity Press. 


\section{International Conference on Advanced Research in SOCIAL SCIENCES}

March 7-9, 2019, London - United Kingdom

Bourdieu, Pierre. 1977. Outline of a Theory and Practice. Cambridge: Cambridge University Press.

Bourdieu, Pierre. 2002. "Habitus." In Habitus: A Sense of Place, edited by Jean Hillier, and Emma Rooksby, 27-33. Burlington: Ashgate Publishing Limited.

Bloom, William. 1990. Personal Identity, National Identity, and International Relations.

Cambridge: Cambridge University Press.

Booth, W. James. 1999. \Communities of Memory: On Identity, Memory, and Debt." American Political Science Review 93:249\{264.

Brubaker, Rogers and Frederick Cooper. 1999. \Beyond Identity." Theory and Society. Forthcoming.

Byron L. Zamboanga, Liliana Rodriguez ,Seth J. Schwartz ,Sherry C. Wang. The structure of cultural identity in an ethnically diverse sample of emerging adults.

Calhoun, Craig. 1991. IThe Problem of Identity in Collective Action." In Macro-Micro

Linkages in Sociology, ed. Joan Huber. Newbury Park, CA: Sage.

Dean, Trevor. 2001. Crime in medieval Europe 1200-1550. Harlow: Longman.

Doherty, Ben. 2006. "Ten years on, the horrors of Port Arthur linger." The Age, April 28. Accessed October 1, 2009.

Erikson, Erik H. 1968. Identity: Youth and Crisis. New York: Norton.

Foucault, Michel. 1995. Discipline and Punish: The Birth of the Prison. New York: Random House, Inc.

Foucault, Michel. 2009. The Archaeology of Knowledge. London: Routledge Classics.

Foucault, Michel. 1989. The Order of Things: An archaeology of the human sciences. London: Routledge.

Huzam Kaddoura. Siham Malkawi.Ontology of Amman: Soul and Body: study of the development of the Arab modern city.

Gleason, Philip. 1983. Identifying Identity: A Semantic History." Journal of American History 6:910\{931.

Jenkins, Richard. 1996. Social Identity. London: Routledge.

Jennifer Tran, 2009. Static Illusions: Architectural Identity, Meaning and History. Curtin University. 


\section{International Conference on Advanced Research in SOCIAL SCIENCES}

March 7-9, 2019, London - United Kingdom

James D. Fearon. November 3, 1999. What is identity ( as we now use the word?).

Department of Political Science. Stanford University.

Laitin, David D. 1998. Identity in Formation. Ithaca, NY: Cornell University Press.

Michael Hitchcock, Victort.King. Discourses with the past: tourism and heritage in South-East Asia. Indonesia and the Malay World, Vol. 31, No. 89, March 2003.

Miller, John, and Hedrich Blessing. Farnsworth House photos. Image. n.d. From Farnsworth House, http://www.farnsworthhouse.org/photos.htm (accessed October 1, 2009).

Dr.Mamdouh Al-Abadi.1996. Amman: Realities and expectations. Issue on cultural, environment and construction. Conference held at the royal Cultural Center, Amman,27-29 June 1995. 